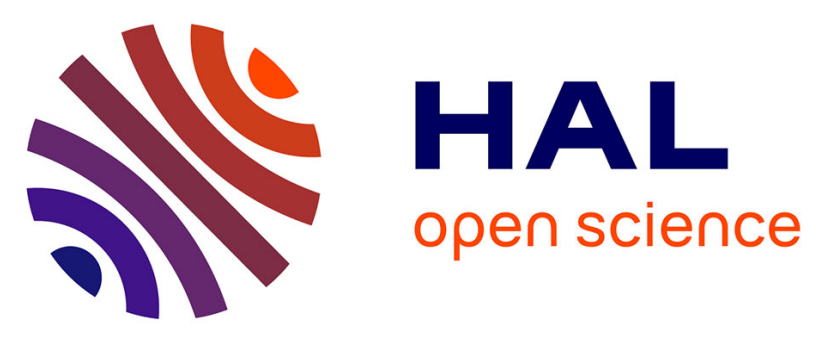

\title{
Altered dietary carbohydrates significantly affect gene expression of the major glucosensing components in Brockmann bodies and hypothalamus of rainbow trout
}

Sergio Polakof, Stéphane Panserat, Elisabeth Plagnes, José L. Soengas

\section{- To cite this version:}

Sergio Polakof, Stéphane Panserat, Elisabeth Plagnes, José L. Soengas. Altered dietary carbohydrates significantly affect gene expression of the major glucosensing components in Brockmann bodies and hypothalamus of rainbow trout. AJP - Regulatory, Integrative and Comparative Physiology, 2008, 295 (4), pp.R1077-R1088. 10.1152/ajpregu.90476.2008 . hal-02668423

\section{HAL Id: hal-02668423 \\ https://hal.inrae.fr/hal-02668423}

Submitted on 31 May 2020

HAL is a multi-disciplinary open access archive for the deposit and dissemination of scientific research documents, whether they are published or not. The documents may come from teaching and research institutions in France or abroad, or from public or private research centers.
L'archive ouverte pluridisciplinaire HAL, est destinée au dépôt et à la diffusion de documents scientifiques de niveau recherche, publiés ou non, émanant des établissements d'enseignement et de recherche français ou étrangers, des laboratoires publics ou privés. 
Sergio Polakof, Stéphane Panserat, Elisabeth Plagnes-Juan and José L. Soengas

Am J Physiol Regulatory Integrative Comp Physiol 295:1077-1088, 2008. First published Aug 6, 2008; doi:10.1152/ajpregu.90476.2008

You might find this additional information useful...

This article cites 54 articles, 28 of which you can access free at:

http://ajpregu.physiology.org/cgi/content/full/295/4/R1077\#BIBL

This article has been cited by 2 other HighWire hosted articles:

Gut glucose metabolism in rainbow trout: implications in glucose homeostasis and glucosensing capacity

S. Polakof, R. Alvarez and J. L. Soengas

Am J Physiol Regulatory Integrative Comp Physiol, July 1, 2010; 299 (1): R19-R32.

[Abstract] [Full Text] [PDF]

Metformin improves postprandial glucose homeostasis in rainbow trout fed dietary carbohydrates: a link with the induction of hepatic lipogenic capacities?

S. Panserat, S. Skiba-Cassy, I. Seiliez, M. Lansard, E. Plagnes-Juan, C. Vachot, P. Aguirre, L. Larroquet, G. Chavernac, F. Medale, G. Corraze, S. Kaushik and T. W. Moon

Am J Physiol Regulatory Integrative Comp Physiol, September 1, 2009; 297 (3): R707-R715.

[Abstract] [Full Text] [PDF]

Updated information and services including high-resolution figures, can be found at:

http://ajpregu.physiology.org/cgi/content/full/295/4/R1077

Additional material and information about American Journal of Physiology - Regulatory, Integrative and Comparative Physiology can be found at:

http://www.the-aps.org/publications/ajpregu

This information is current as of September 7, 2010 .

The American Journal of Physiology - Regulatory, Integrative and Comparative Physiology publishes original investigations that illuminate normal or abnormal regulation and integration of physiological mechanisms at all levels of biological organization, ranging from molecules to humans, including clinical investigations. It is published 12 times a year (monthly) by the American

Physiological Society, 9650 Rockville Pike, Bethesda MD 20814-3991. Copyright @ 2008 by the American Physiological Society. ISSN: 0363-6119, ESSN: 1522-1490. Visit our website at http://www.the-aps.org/. 


\title{
Altered dietary carbohydrates significantly affect gene expression of the major glucosensing components in Brockmann bodies and hypothalamus
}

\author{
of rainbow trout
}

\author{
Sergio Polakof, ${ }^{1}$ Stéphane Panserat, ${ }^{2}$ Elisabeth Plagnes-Juan, ${ }^{2}$ and José L. Soengas ${ }^{1}$ \\ ${ }^{1}$ Laboratorio de Fisioloxía Animal, Departamento de Bioloxía Funcional e Ciencias da Saúde, Facultade de Bioloxía, \\ Universidade de Vigo, Vigo, Spain; and ${ }^{2}$ Institut National de la Recherche Agronomique, Unité Mixte de Recherche 1067 \\ Nutrition Aquaculture and Genomique, Pôle d'Hydrobiologie, CD918, St.-Pée-sur-Nivelle, France
}

Submitted 5 June 2008; accepted in final form 4 August 2008

Polakof S, Panserat S, Plagnes-Juan E, Soengas JL. Altered dietary carbohydrates significantly affect gene expression of the major glucosensing components in Brockmann bodies and hypothalamus of rainbow trout. Am J Physiol Regul Integr Comp Physiol 295: R1077-R1088, 2008. First published August 6, 2008; doi:10.1152/ajpregu.90476.2008.-Carnivorous fish have a limited capacity to utilize dietary carbohydrates even though glucosensing components exist in the hypothalamus and Brockmann bodies. Therefore, we fed trout for 10 days with two experimental diets containing a high level of carbohydrates $(20 \%)$ or a carbohydrate-free level $(<0.3 \%)$ to test the capacity of dietary carbohydrates to regulate gene expression of glucosensing components. Fish were fed and killed 1, 6, and $24 \mathrm{~h}$ after the meal to analyze plasma glucose levels, glucosensing-related biochemical parameters, and gene expression of the major components of the glucosensing system in the hypothalamus and Brockmann bodies. Glucose facilitative transporter type 2 and glucokinase gene expression were confirmed by real-time PCR data and two new components of the glucosensing mechanism, Kir6.-like and sulfonylurea receptor-like, were detected for the first time in fish in both tissues. In addition, a clear adaptation to dietary carbohydrates was found in trout Brockmann bodies, based on increased gene expression of major components of the system as well as enhanced glucokinase activities and glycogen levels. In contrast, in the hypothalamus, only glucokinase gene expression and activity showed a response to dietary carbohydrates, supporting the key role of that enzyme in glucosensing mechanism. Finally, a differential postprandial profile was found between tissues regarding the glucosensing potential, since the hypothalamus seems to respond to hyperglycemia earlier than the Brockmann bodies, whose response took place later. Altogether, these data describe for the first time in fish a complete response of major glucosensing components to dietary carbohydrates in trout hypothalamus and Brockmann bodies, supporting an efficient adaptation of both tissues to those dietary components.

dietary carbohydrates; GK; $\mathrm{K}_{\mathrm{ATP}}$; GLUT; rainbow trout

IN FISH, THE CARNIVOROUS SPECIES (whose natural diet is based on insects and small fish) are recognized for their limited capacity to utilize dietary carbohydrates for energy purposes (55). In this sense, carnivorous fish require high protein (amino acids) for protein synthesis and energy purposes (41). However, because protein is one of the most expensive components of diets and its excess increases $\mathrm{N}$ excretion in the aquatic environment, it is advisable for sustainable aquaculture to spare protein by increasing the utilization of conventional and

Address for reprint requests and other correspondence: S. Polakof, Laboratorio de Fisioloxía Animal, Facultade de Bioloxía, Edificio de Ciencias Experimentais, Universidade de Vigo, E-36310 Vigo, Spain (e-mail: spolakof @uvigo.es).

http://www.ajpregu.org

0363-6119/08 \$8.00 Copyright ๑ 2008 the American Physiological Society

R1077 cheaper energy sources like carbohydrates (12). Nevertheless, most teleosts do not tolerate high dietary carbohydrate levels, and the maximum dietary inclusion level depends on the fish species (55). This inability is characterized by prolonged postprandial hyperglycemia after a carbohydrate-rich diet intake or oral glucose administration $(24,55)$ and even impaired growth (10). Even though the basis for this apparent glucose intolerance remains poorly understood, several hypotheses have been proposed (24), including an unbalance between hepatic glucose phosphorylation and glucose-6-phosphate hydrolysis, the weak capacity of glucose to act as insulin secretagogue compared with amino acids, relatively low numbers of muscle glucose transporters, and/or insulin receptors, and low glucose phosphorylation capacity in muscle.

However, other evidences obtained in fish suggest that plasma glucose levels would be under certain controls, including 1) plasma glucose levels are reported to fluctuate after feeding (32); 2) certain organs, like the brain, rely on glucose as a primary fuel (46); and 3) glucose use in the bullrout brain increased under hypoglycemic conditions (17). In this sense, in fishes like rainbow trout, a system similar to that proposed in mammals (16) involved in the detection of changes in circulating glucose levels seems to be functional (33). In mammals, the glucosensing system has been described in pancreatic $\beta$-cells (42) and glucose-excited neurons of the hypothalamus and brain stem (16). In these tissues, after a rise in glycemia, glucose is transported across the cell membrane through a glucose facilitative transporter type 2 (GLUT2) carrier and metabolized by glucokinase (GK) to glucose-6-phosphate that enters in glycolysis and the Krebs cycle. The metabolism of glucose results in increases in cellular ATP that lead to closure of ATP-sensitive inward rectified $\mathrm{K}^{+}$channels $\left[\mathrm{K}_{\mathrm{ATP}}\right.$; comprising Kir6.x subunits and sulfonylurea receptor type-1 (SUR1) receptors], leading to membrane depolarization, $\mathrm{Ca}^{2+}$ influx, and insulin release or increased firing rate, respectively (42). Moreover, in mammals, increases of fatty acid synthase tation process of $\beta$-cells to hyperglycemia (38), whereas FAS mRNA is upregulated in hypothalamic neurons in response to glucose (14).

Using rainbow trout as a model of a carnivorous species, we have demonstrated in previous studies that several tissues act as glucosensors in fishes, responding to increases or decreases

The costs of publication of this article were defrayed in part by the payment of page charges. The article must therefore be hereby marked "advertisement" of page charges. The article must therefore be hereby marked "advertise
in accordance with 18 U.S.C. Section 1734 solely to indicate this fact. (FAS) gene expression have also been related to the adap- 
in glucose levels either in vivo $(33,35)$ or in vitro $(34)$ with concomitant changes in GK activity and/or expression, glycolytic potential, and levels of glucose and glycogen in a way similar to the metabolic responses occurring in mammalian glucosensor systems (16). The tissues involved in this response include brain regions such as the hypothalamus and hindbrain as well as the Brockmann bodies (BB, a distinct grouping of pancreatic endocrine cells near to the gall bladder; Ref. 56).

Data available on gene regulation of glucosensing components by dietary carbohydrates in rainbow trout are restricted to long-term expression of GK and GLUT2 measured in days not hours after the feeding treatment and using low sensitive standard PCR approaches (35). Moreover, no information is available regarding other components of the glucosensing mechanism known in mammals, such as Kir or SUR proteins for which pharmacological evidence of their existence was obtained by us in previous studies (34). Therefore, considering the presence of glucosensor areas in both fish hypothalamus and BB (33) and the capacity of dietary carbohydrate to elicit changes in the glucosensor system during long-term approaches (35), the aim of this study using rainbow trout fed with carbohydrate-free or carbohydrate-enriched diets was as follows: 1) to determine if other components of the glucosensing machinery (Kir and SUR) are present in two typical glucosensing tissues like the hypothalamus and $\mathrm{BB}$; 2) to determinate if the presence and/or absence of dietary carbohydrates can regulate gene expression (using real-time RT-PCR data) of the major actors of the glucosensing system (GLUT2, GK, Kir, and SUR) and can also affect the biochemical response of key glucosensing-related parameters; and 3) to characterize the postprandial kinetic profile $(1,6$, and $24 \mathrm{~h}$ after the last meal) of gene expression and biochemical parameters related to the glucosensing function in trout fed with a carbohydrate-enriched diet.

\section{MATERIALS AND METHODS}

Fish and diets. Rainbow trout (Oncorhynchus mykiss Walbaum) were obtained from a local fish hatchery (Soutorredondo, Spain). Fish were maintained for 1 mo in 100-liter tanks under laboratory conditions and a natural photoperiod in dechlorinated tap water at $16^{\circ} \mathrm{C}$. Fish mass was $113 \pm 6 \mathrm{~g}$. Fish were fed specifically daily during the whole acclimation period with commercial dry fish pellets (DibaqDiproteg, Segovia, Spain; proximate food analysis was $48 \%$ crude protein, $6 \%$ carbohydrates, $25 \%$ crude fat, and $11.5 \%$ ) to satiety. Then, fish were distributed in six tanks (14 fish per tank) and were fed similar amounts of food $(\sim 2 \%$ body wt) once at day, as in the acclimation period, during 10 days with two formulated dry diets: a high-carbohydrate (HC) diet and a carbohydrate-free (CF) diet (Table 1). Crude protein analysis (as Nx6.25) was measured by nitrogen determination (mass spectrometer VG Autospec M) and starch levels following Thivend et al. (48). On the day of sampling, fish were fed, and then 14 fish $(n=8$ to assess enzyme activities and metabolites levels and $n=6$ to assess gene expression) from each experimental group were anesthetized with MS-222 (50 mg/l buffered to $\mathrm{pH} 7.4$ with sodium bicarbonate), weighed, and killed 1, 6, and $24 \mathrm{~h}$ after the meal. Blood was sampled from the caudal vein into ammoniumheparinized syringes, centrifuged $(5,000 \mathrm{~g})$, and analyzed enzymatically for plasma glucose concentration using a commercial kit (Biomérieux) adapted to a microplate format. The liver, hypothalamus, and $\mathrm{BB}$ were removed, freeze-clamped in liquid nitrogen, and stored at $-80^{\circ} \mathrm{C}$ until assayed. The experiments described comply with the Guidelines of the European Union Council (86/609/EU) and of the Spanish Government (RD 1201/2005) for the use of animals in
Table 1. Composition and proximate analyses of the two experimental diets

\begin{tabular}{|c|c|c|}
\hline & \multicolumn{2}{|c|}{ Diets } \\
\hline & $\mathrm{CF}$ & $\mathrm{HC}$ \\
\hline \multicolumn{3}{|l|}{ Ingredients, $\%$} \\
\hline Fish meal* & 85.8 & 66.1 \\
\hline Gelatinized starch*† & 0 & 10.5 \\
\hline Sucrose & 0 & 3.3 \\
\hline Fish oil* & 12.2 & 18.1 \\
\hline Vitamin mixture*§ & 1 & 1 \\
\hline Mineral mixture*§ & 1 & 1 \\
\hline \multicolumn{3}{|c|}{ Proximate analyses (dry matter basis) } \\
\hline Dry matter, \% & 85.3 & 83.3 \\
\hline Crude protein, \%dry matter & 69 & 43 \\
\hline Digestible starch, \%dry matter & $<0.3$ & 20 \\
\hline
\end{tabular}

*Purchased from Dibaq-Diprotg; †potato starch; $\neq$ purchased from Sigma; §purchased from Kent Marine (Franklin, WI).

research and were approved by the Ethics Committee of the University of Vigo (Spain).

Assessment of GK activity and glycogen levels. Frozen tissues were quickly minced on a chilled Petri dish to very small pieces that (still frozen) were divided into two homogeneous portions to assess GK activity and glycogen levels. The tissue portions used to assess glycogen levels were homogenized immediately by ultrasonic disruption in $7.5 \mathrm{vol}$ of ice-cooled 6\% PCA and neutralized (using $1 \mathrm{~mol} / \mathrm{l}$ potassium bicarbonate). The homogenate was centrifuged, and the supernatant was used to assay tissue glycogen levels using the method of Keppler and Decker (13). Glucose obtained after glycogen breakdown (after free glucose levels were subtracted) was determined with a commercial kit (Biomérieux). GK activities (expressed per mg of protein) were monitored in a microplate reader SPECTRAFluor (Tecan, Grödig, Austria) by changes in the concentrations of $\beta-\mathrm{NADP}^{+}$and involved the use of a coupling enzyme added in excess (15). Protein was assayed in triplicate in homogenates using microplates according to the bicinchoninic acid method (45) with BSA (Sigma, St. Louis, MO) as a standard. One unit of the enzyme activity was defined as the amount of enzyme that catalyzed the hydrolysis of $1 \mu \mathrm{mol}$ of substrate under the specified conditions $\left(37^{\circ} \mathrm{C}\right)$.

Total RNA extraction and processing and gene expression levels by real-time PCR. Total RNA was extracted using TRIzol reagent (Invitrogen, Carlsbad, CA), and gene mRNA levels were determined by RT-PCR. RNA quantity and quality were determined by capillary electrophoresis using the Lab-on-a-Chip technique (Agilent 2100 Bioanalyzer, Agilent Technologies, Waldbronn, Germany) in accordance with the manufacturer's instructions on the RNA 6000 Nano Labchip. Only samples with $28 \mathrm{~S}$-to-18S rRNA ratios $>1.7$ were accepted. cDNA was generated from $1 \mu \mathrm{g}$ RNA (liver and BB) and $500 \mathrm{ng}$ (hypothalamus) using SuperScript III RNase H-reverse transcription system (Invitrogen). Real-time PCR was performed in the MyiQ cycler (Bio-Rad, Hercules, CA). Quantitative (q) PCR analyses were performed on $10 \mu \mathrm{l}$ of the diluted RT reaction mixture (dilution $1 / 40$ for all genes, treatments, and sampling times) using the iQ SYBR Green Supermix (Bio-Rad). The total volume of the PCR reaction was $25 \mu \mathrm{l}$, containing $100 \mathrm{nM}$ of each primer (Table 2). Primers were designed so that they are overlapping an intron (Primer3 software; Whitehead Institute for Biomedical Research/MIT Center, Cambridge, MA) using known sequences in nucleotide databases [Genbank: http://www.genome.ad.jp/htbin/www_bfind?dnatoday; and National Institute of Agronomic Research (INRA)-Sigenae: http:// ensembl-sigenae.jouy.inra.fr/]. Accession numbers for rainbow trout genes were as follows: gb AF053331-Genbank (gk); gb AF321816 -Genbank (GLUT2); tcaa0001c.m.06_5.1.om.4Sigenae (fas); and tcce0019d.e.20_3.1.s.om.8-Sigenae (sur-like; which was highly similar to SUR amino acid sequence from Rattus 
Table 2. Nucleotide sequences of the PCR primers used to assay gene expression by RT-PCR

\begin{tabular}{|c|c|c|c|c|}
\hline & Forward Primer & Reverse Primer & Annealing Temperature, ${ }^{\circ} \mathrm{C}$ & PCR Product Length, bp \\
\hline GK & gcacggctgagatgctctttg & gccttgaaccctttggtccag & 60 & 169 \\
\hline SUR-like & cgaggactggccccagca & gactttccacttcctgtgcgtcc & 62 & 150 \\
\hline FAS & tgatctgaaggcccgtgtca & gggtgacgttgccgtggtat & 60 & 161 \\
\hline
\end{tabular}

GK, glucokinase; GLUT2, glucose facilitative transporter type 2; Kir6.-like, inward rectifier $\mathrm{K}^{+}$channel pore type 6.-like; SUR-like, sulfonylurea receptor-like; FAS, fatty acid synthase.

norvegicus, $P=10^{-143}$ ) and CA346261.1.s.om.8 dna: contig: CA346261.1.s.om.8:1:773:1-Sigenae (Kir6.-like; which was highly similar to Kir amino acid sequence from Rattus norvegicus, $P=10^{-66}$ ) for the first time in this species. The qPCR amplified products were checked for specificity by sequencing.

Relative quantification of the target gene transcript was done using $\beta$-actin gene expression as a reference. Thermal cycling was initiated with the incubation at $95^{\circ} \mathrm{C}$ for $90 \mathrm{~s}$ for hot-start iTaq DNA polymerase activation and continued with a two-step amplification program $\left(20 \mathrm{~s}\right.$ at $95^{\circ} \mathrm{C}$ followed by $30 \mathrm{~s}$ at specific primer hybridization temperature; see Table 2 for details) repeated 35 times. After the final cycle of the PCR, melting curves were systematically monitored $\left(55^{\circ} \mathrm{C}\right.$ temperature gradient at $0.5^{\circ} \mathrm{C} / \mathrm{s}$ from 55 to $94^{\circ} \mathrm{C}$ ) to ensure that only one fragment was amplified. Samples without reverse transcriptase and samples without RNAs were run for each reaction as negative controls. Each sample was analyzed four times, since two retrotranscription replicates and two amplification replicates were performed. All the replicates of each sample were located in the same plate for each gene to allow comparisons. The plate setup was as follows: from Figs. 2 to 4 for each gene, we utilized three plates, each one containing the samples from both diet group (CF and HC) at each hour (1, 6, and $24 \mathrm{~h}$ ). For Fig. 5, the plate setup was one plate for each gene, with all the sampling times in the same plate. We included in all the plates the standard curve (by triplicate) and blanks for DNA, PCR, and retrotranscription (by duplicate). Only efficiency values between $85-100 \%$ were accepted, and the $R^{2}$ for all the genes assessed was always $>0.985$.

Relative quantification of target gene expression was performed using the mathematical model described by Pfaffl (30). The relative expression ratio $(\mathrm{R})$ of a target gene was calculated on the basis of real-time PCR efficiency $(\mathrm{E})$ and the threshold cycle $\left(\mathrm{C}_{\mathrm{T}}\right)$ deviation $\left(\Delta \mathrm{C}_{\mathrm{T}}\right)$ of the unknown sample vs. a control sample and expressed compared with the $\beta$-actin reference gene. $\beta$-Actin gene expression did not show significant differences among samples, treatments, or sampling times.

$$
\mathrm{R}=\frac{\left(\mathrm{E}_{\text {target gene }}\right)^{\Delta \mathrm{CT} \text { target gene (mean control-mean sample) }}}{\left(\mathrm{E}_{\beta \text {-actin }}\right)^{\Delta \mathrm{CT} \beta \text {-actin (mean control-mean sample) }}}
$$

PCR efficiency (E) was measured by the slope of a standard curve using serial dilution of cDNA.

Statistics. Data are means \pm SE. Comparisons among groups and times for biochemical parameters were performed using a two-way ANOVA (SigmaStat; SPSS, Chicago, IL) with diet (HC and CF) and time $(1,6$, and $24 \mathrm{~h})$ as independent variables. Post hoc comparisons were made using a Student-Newman-Keuls test, and differences were considered statistically significant at $P<0.05$. Comparisons among diets groups ( $\mathrm{HC}$ and $\mathrm{CF}$ ) for gene expression were performed using a Student's $t$-test $(P<0.05)$, whereas comparisons among times within the HC group were made using a one-way ANOVA.

\section{RESULTS}

Glycemia. After the animals were fed 10 days with the $\mathrm{CF}$ diet, plasma glycemia (Fig. 1) did not show any significant modification of the postprandial profile. In contrast, the postprandial glycemia kinetics in the HC fish displayed a significant maximum level at $6 \mathrm{~h}$ postfeeding $(P<0.05)$, recovering the same level than $1 \mathrm{~h}$ after feeding $24 \mathrm{~h}$ later. Moreover, as expected, the levels of plasma glucose in fish fed HC diet were always significantly higher than in trout fed with the $\mathrm{CF}$ diet $(P<0.05)$.

Effects of high levels vs. low levels of dietary carbohydrates on gene expression. The effects on GK, GLUT2, Kir6.-like, SUR-like, and FAS gene expression of HC or CF dietary intake in the hypothalamus are shown in Fig. 2. GK gene expression was twofold higher in fish fed with the HC diet than in those fed with the CF diet whatever was the postprandial timing (1, 6 , and $24 \mathrm{~h}$ ). In contrast, lower GLUT2 gene expression was found in trout fed with the $\mathrm{HC}$ diet than in those fed with the $\mathrm{CF}$ diet only $6 \mathrm{~h}$ postfeeding. No other changes were noticed whatever genes or times were assessed.

GK, GLUT2, Kir6.-like, SUR-like, and FAS gene expression in $\mathrm{BB}$ of trout fed with a $\mathrm{HC}$ or $\mathrm{CF}$ diet is displayed in Fig. 3. Higher gene expression was observed in trout fed with the $\mathrm{HC}$ diet than in those fed with the CF diet $1 \mathrm{~h}$ postfeeding for all the genes assessed except for Kir6.-like (Fig. 3A). In contrast, at $6 \mathrm{~h}$ postfeeding (Fig. 3B), all the genes studied were differentially expressed between the dietary treatments. At $24 \mathrm{~h}$ postfeeding (Fig. 3C), only Kir6.-like and SUR-like showed

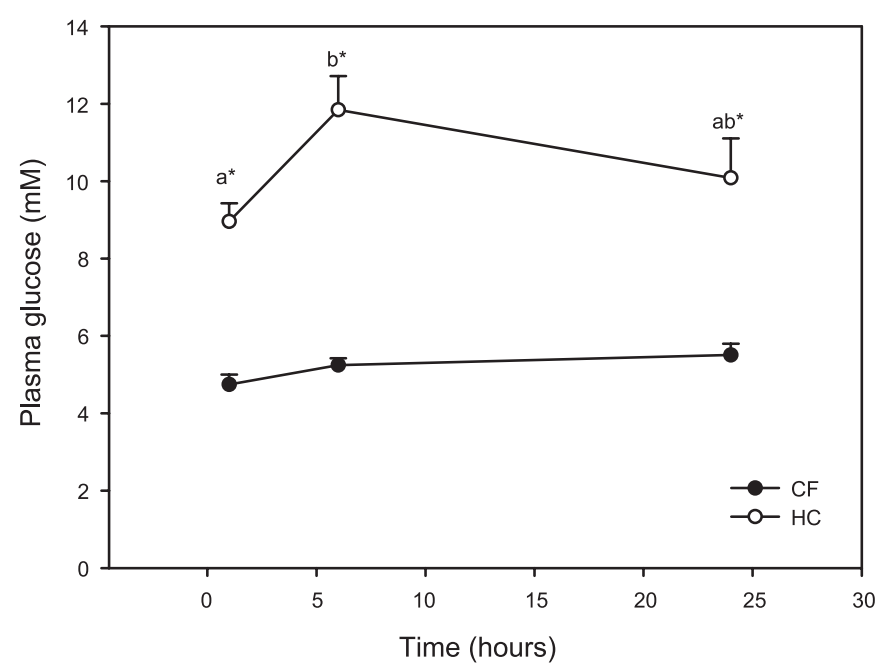

Fig. 1. Glucose levels in plasma of rainbow trout fed with or without carbohydrates during 10 days and sampled 1,6 , and $24 \mathrm{~h}$ after the last meal. Values are means $\pm \mathrm{SE} ; n=14$. *Significantly different from carbohydratefree $(\mathrm{CF})$ diet $(P<0.05)$. Different letters indicate significant differences $(P<$ $0.05)$ among times within each treatment $[\mathrm{CF}$ and high-carbohydrate $(\mathrm{HC})$ diet]. 


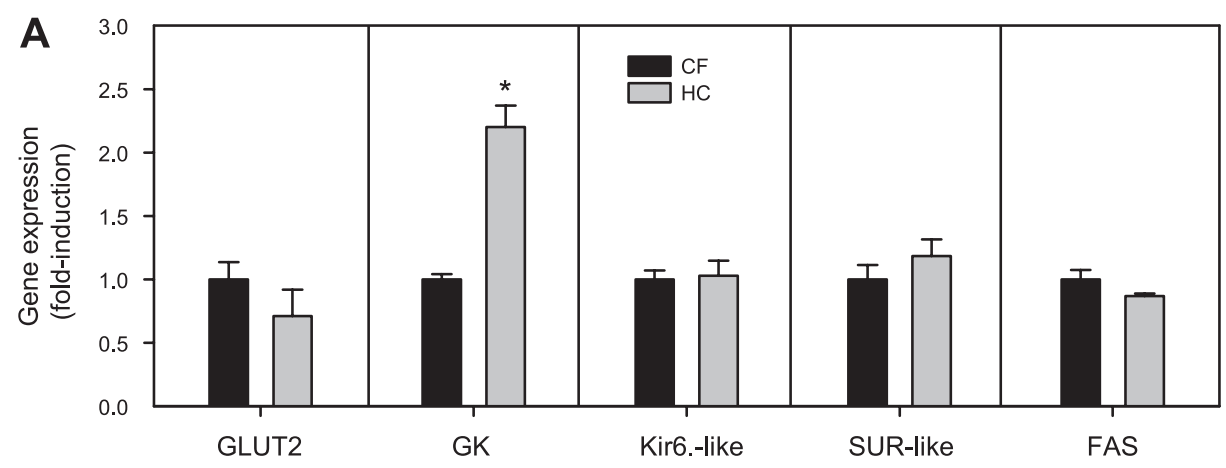

Fig. 2. Glucose facilitative transporter type 2 (GLUT2), glucokinase (GK), sulfonylurea receptor (SUR)-like, Kir6.-like, and fatty acid synthetase (FAS) gene expression in hypothalamus of rainbow trout fed with or without carbohydrates during 10 days. Differences in mRNA expression between fish fed with the 2 experimental diets (CF and $\mathrm{HC})$ were analyzed $1(A), 6$ $(B)$, and $24 \mathrm{~h}(C)$ after the last meal and presented as fold induction. Expression results were normalized to $\beta$-actin expression, which did not change with treatment. Values are means \pm SE; $n=6$. *Significantly different from $\mathrm{CF}$ $\operatorname{diet}(P<0.05)$.
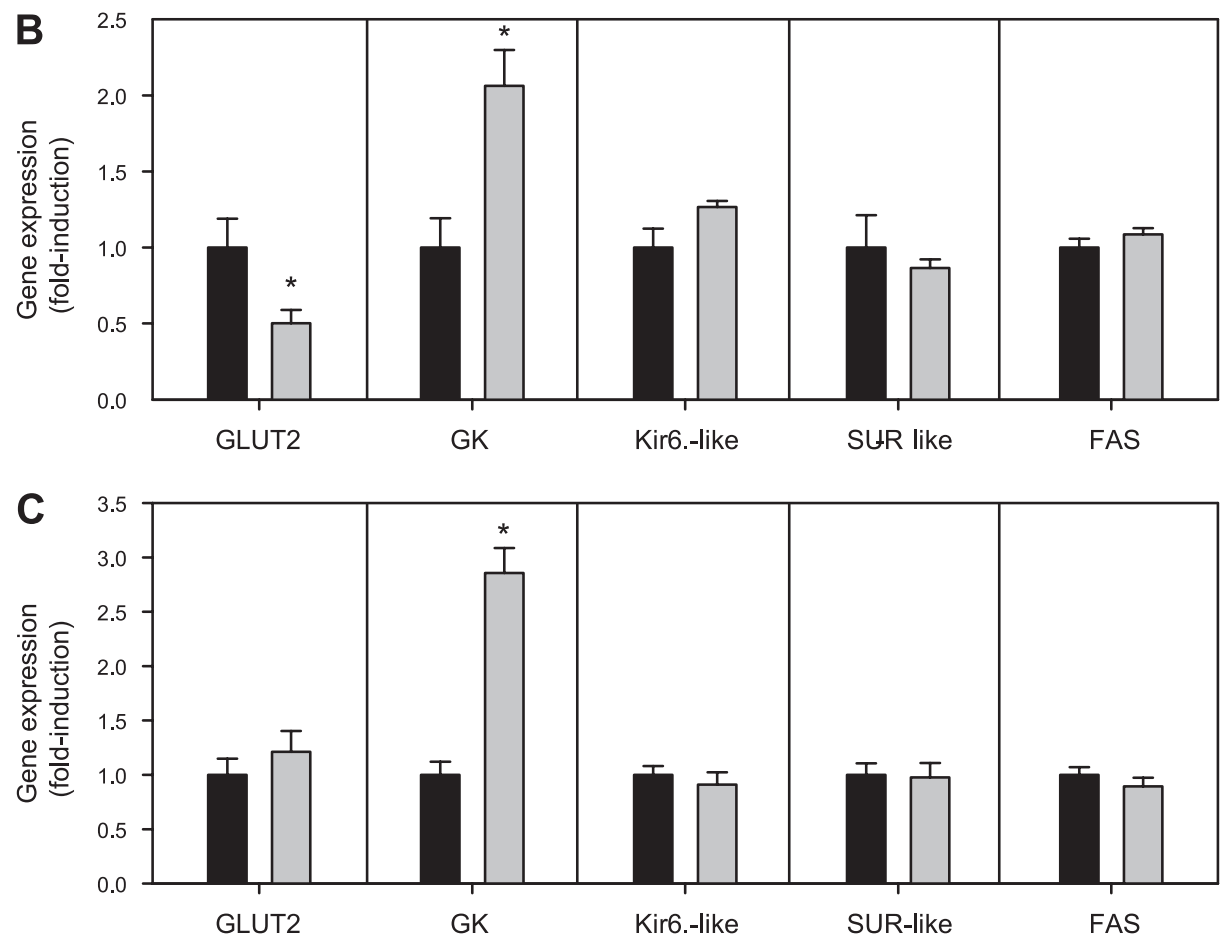

higher levels of expression in fish fed with the HC diet than in fish fed with the CF diet.

Liver was studied as well-known internal control of dietary carbohydrate intake on parameters assessed. Liver GLUT2, GK, and FAS gene is are shown in Fig. 4. GK and FAS gene expression is clearly higher in trout fed with the HC diet than in fish fed with the CF diet at all the times assessed, even showing a 200 -fold induction for GK (6 h postfeeding) and 6-fold for FAS ( $24 \mathrm{~h}$ postfeeding). In contrast, no significant differences were noticed in GLUT2 gene expression whatever the postprandial timings were.

Postprandial kinetics of gene expression after HC intake. GLUT2 gene expression (Fig. 5A) did not show any changes in liver. However, in BB the GLUT2 gene expression was lower at $24 \mathrm{~h}$ than at $6 \mathrm{~h}$ and in the hypothalamus it was lower at 6 and $24 \mathrm{~h}$ compared with $1 \mathrm{~h}$. GK gene expression (Fig. 5B) showed a postprandial increase in liver, with maximum values 6 and $24 \mathrm{~h}$ postfeeding (6-fold induction). In contrast, no postprandial changes were found in either $\mathrm{BB}$ or the hypothalamus. In BB, we found a maximum of gene expression $6 \mathrm{~h}$ postfeeding. FAS gene expression (Fig. $5 E$ ) in both liver and BB displayed a postprandial increase, with maximum levels of expression at 6 and $24 \mathrm{~h}$. However, in the hypothalamus, the opposite situation was found, with minimum levels of FAS gene expression $24 \mathrm{~h}$ postfeeding. A peak of Kir6.-like (Fig. $5 C$ ) gene expression was observed $6 \mathrm{~h}$ postfeeding in BB. In the hypothalamus, in contrast, we found a minimum of expression $24 \mathrm{~h}$ after feeding. SUR-like gene expression (Fig. 5D) did not show postprandial significant differences in the hypothalamus.

Metabolic markers of carbohydrate intake: GK activities and glycogen levels. GK activities (Fig. 6) in fish fed with the $\mathrm{CF}$ diet only showed a significant decrease in BB $24 \mathrm{~h}$ postfeeding. In contrast, in fish fed with the $\mathrm{HC}$ diet a postprandial increase in GK activity was observed in both liver and $\mathrm{BB}$, with a trend to return to basal levels in the last one $(24 \mathrm{~h}$ postfeeding). In contrast to those profiles, in the hypothalamus of trout fed with the HC diet, the maximum GK activity was found $1 \mathrm{~h}$ postfeeding and then decreased significantly from this time up to $24 \mathrm{~h}$.

No significant differences were found in glycogen levels in fish fed with the CF diet (Fig. 6) either with time or diets, except in BB where levels were lower at $24 \mathrm{~h}$ than at 1 and $6 \mathrm{~h}$. 

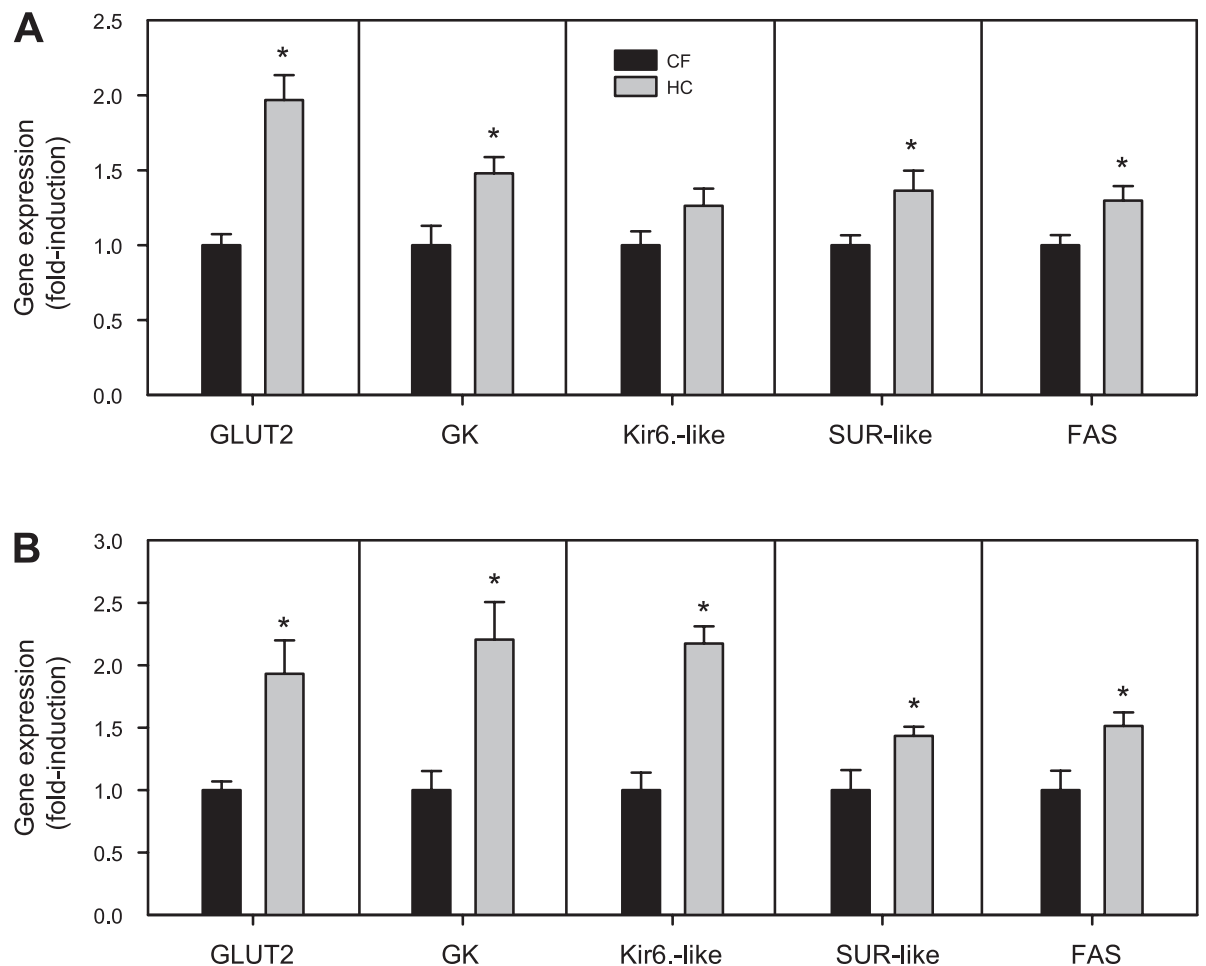

Fig. 3. GLUT2, GK, SUR-like, Kir6.-like, and FAS gene expression in Brockmann bodies of rainbow trout fed with or without carbohydrates during 10 days. Differences in mRNA expression between fish fed with the 2 experimental diets (CF and $\mathrm{HC}$ ) were analyzed $1(A), 6(B)$, and $24 \mathrm{~h}(C)$ after the last meal and presented as fold induction. Expression results were normalized to $\beta$-actin expression, which did not change with treatment. Values are means $\pm \mathrm{SE} ; n=6$. *Significantly different from $\mathrm{CF}$ diet $(P<0.05)$.

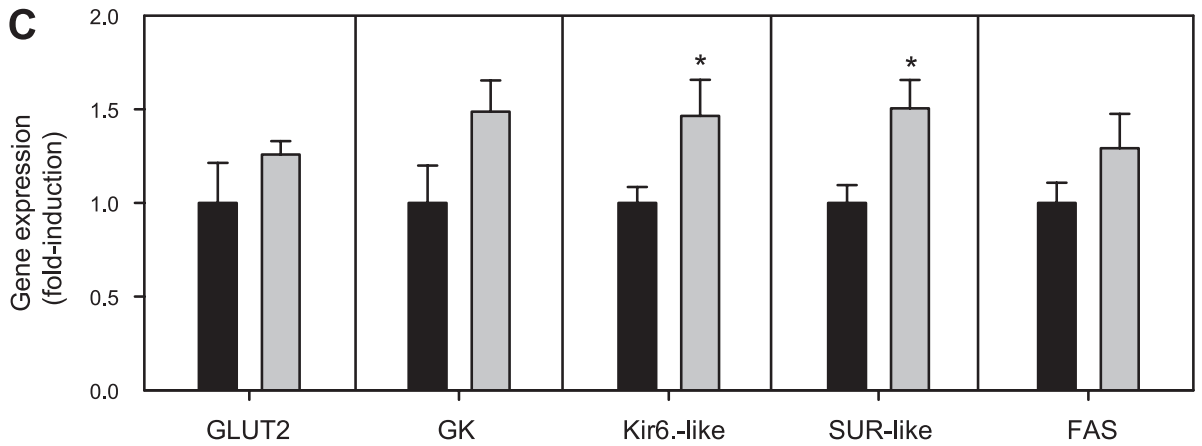

In contrast to fish fed with $\mathrm{CF}$ diet, trout fed with the $\mathrm{HC}$ diet present higher glycogen levels, increasing progressively from $1 \mathrm{~h}$ after feeding to $24 \mathrm{~h}$ in the three tissues assessed. This profile was specially marked in BB, where glycogen levels $6 \mathrm{~h}$ after feeding were twofold higher than $1 \mathrm{~h}$ after the last meal.

\section{DISCUSSION}

Validation of experimental design. In the present study, plasma glucose levels in fish fed for 10 days with a $\mathrm{HC}$ diet were clearly higher than in those fed with a CF diet in agreement with similar studies with rainbow trout $(4,35)$ and other carnivorous species (3). In addition, the postprandial profile found in fish fed with the $\mathrm{HC}$ diet resembles that reported in carnivorous fishes subjected to similar experimental conditions $(4,26)$, reflecting the slow plasma glucose clearance in these animals (24) and supporting the experimental design. On the other hand, the absence of changes among sampling times in trout fed with the $\mathrm{CF}$ diet is similar to that previously addressed in fish fed with similar diets $(3,27)$.
To further validate the experimental design, we also examined some key parameters in liver glucose metabolism known to change under different carbohydrate dietary conditions. Therefore, we found in liver some results reflecting the storage process of glucose in response to the high proportion of dietary carbohydrates in agreement with data in literature, including the following: 1) higher GK activities and expression and glycogen levels in fishes fed with the $\mathrm{HC}$ diet (at all times assessed), with up to 7.5-, 200-, and 30-fold increases, respectively $(35,47) ; 2)$ no transcriptional regulation of GLUT2 gene expression by dietary carbohydrates (28); and 3) a postprandial profile characterized by an increase in GK activity and expression and glycogen levels after a $\mathrm{HC}$ diet intake $(4,27)$. On the other hand, in mammals, transcriptional regulation is the major site that regulates the changes in FAS gene expression caused by a HC diet (29). In the present study, we have demonstrated in fish that, as occurs in mammals (51), hepatic FAS gene expression is markedly upregulated by dietary carbohydrates, supporting the classical hepatic profile in response to dietary 

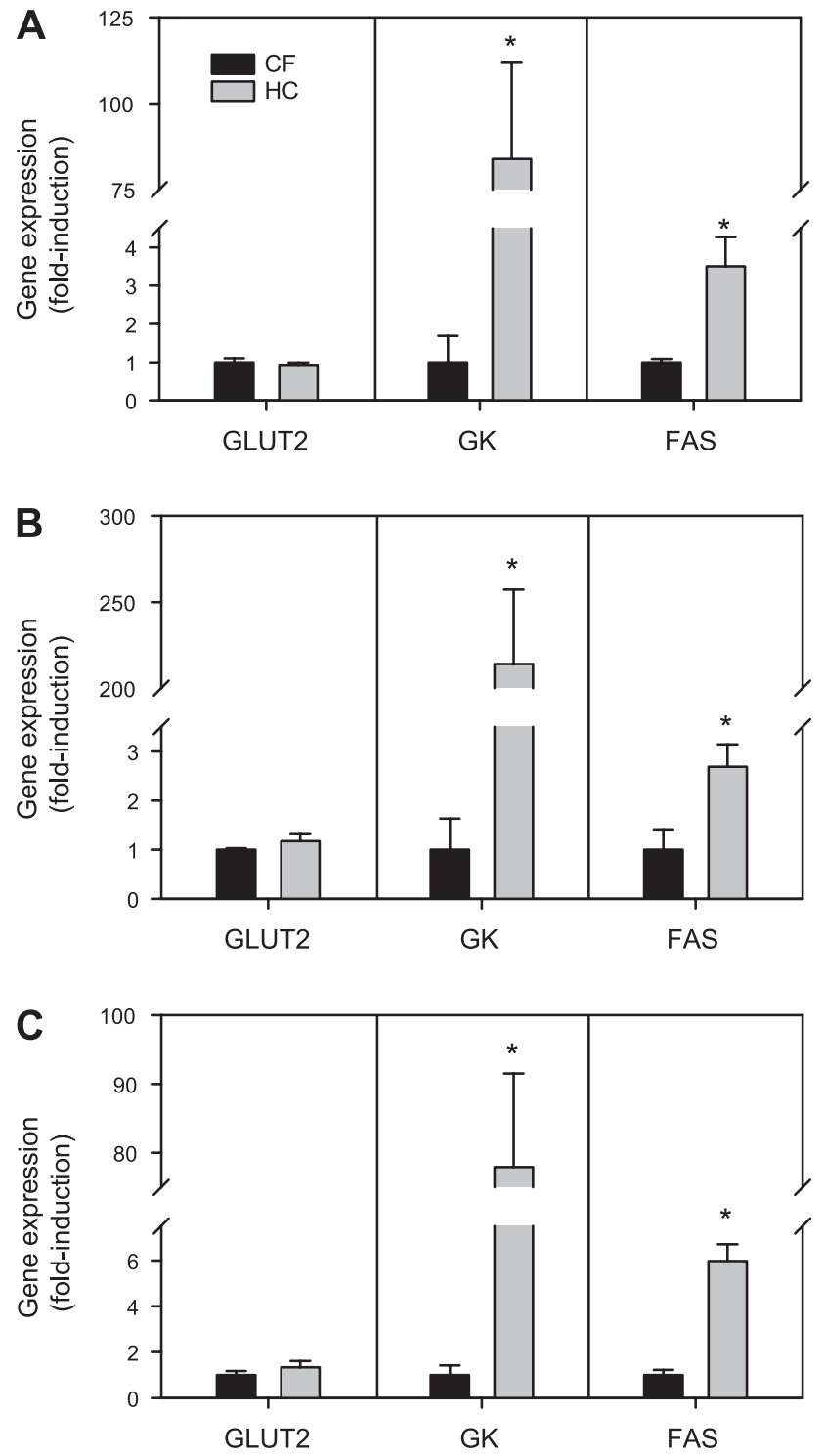

Fig. 4. GLUT2, GK, and FAS gene expression liver of rainbow trout fed with or without carbohydrates during 10 days. Differences in mRNA expression between fish fed with the two experimental diets (CF and $\mathrm{HC}$ ) were analyzed $1(A), 6(B)$, and $24 \mathrm{~h}(C)$ after the last meal and presented as fold induction. Expression results were normalized to $\beta$-actin expression, which did not change with treatment. Values are means $\pm \mathrm{SE} ; n=6$. ${ }^{*}$ Significantly different from $\mathrm{CF}$ and $\mathrm{HP}$ diets $(P<0.05)$.

carbohydrate intake presented above. This is in agreement with our findings such as the fact that FAS activity is enhanced by dietary carbohydrates (47) and FAS expression is stimulated by glucose in vitro in presence of insulin (31). However, the HC diet contains also more lipids than the CF diet and because of that we cannot exclude the possibility that the changes in FAS gene expression may be due to both carbohydrates and lipids present in the diet.

Since carbohydrates were mainly replaced by protein in the $\mathrm{CF}$ diet, $\mathrm{CF}$ fish ingested more protein, and we admit that our experimental conditions do not allow us to distinguish between the potential effects of protein decrease and/or carbohydrate increase. However, in the present study, the diets differ in carbohydrate by $\sim 2,000 \%$ and in protein by only $25 \%$; hence, the change in carbohydrate levels is about two orders of magnitude greater than that of protein and therefore the changes could be mainly attributed to variations in carbohydrate rather than in protein contents. In addition, we consider that in our design the major change that is taking place is between the presence $(20 \%)$ and absence $(<0.3 \%)$ of glucose in the diet. Because of that trout were fed with diets containing a high amount of carbohydrates or not at all, but, inversely, we did not feed trout without protein. As further validation, our targets are all (primarily but not exclusively) sensitive to glucose and not to protein. On the other hand, and due the composition of the diets, we cannot exclude the possibility that the energy and/or lipid contents are playing a role as variables in the system. However, studies about energy and/or lipids influence over the glucosensing system in mammals are not available, even when the glucosensing system is a nutrient sensor that could be regulated by the energy intake.

Effects of dietary carbohydrates on major components of the glucosensing mechanism in BB. Glucose uptake is the initial step in the glucose-stimulated insulin secretion by pancreatic $\beta$-cells, and in rodents GLUT2 is the only glucose transporter normally detected in these cells (49). Even though GLUT2 expression was previously detected in piscine $\mathrm{BB}(33,35)$, those data came from low sensitive standard PCR approaches for semiquantitative analysis of gene expression. Thus, with the data obtained from qPCR, we observed changes in GLUT2 expression that paralleled those of plasma glucose levels, being twofold induced by dietary carbohydrates in fish fed with the $\mathrm{HC}$ diet during the first $6 \mathrm{~h}$ postfeeding compared with those fed with the CF diet, without differences among them $24 \mathrm{~h}$ after the last meal. This stimulation of GLUT2 expression by dietary carbohydrates was also previously reported in rainbow trout feeding with similar diets during a shorter period of time and sampled $6 \mathrm{~h}$ postfeeding (35) and also in glucose-injected fish (33). In addition, in mammals glucose is the major regulator of GLUT2 gene expression in $\beta$-cells (50) and since GLUT2 is not expressed in mammalian $\alpha$-cells (9), our data suggest that in the piscine $\beta$-cells GLUT2 expression is, as occurs mammals (54), stimulated directly by glucose. This situation is in contrast with the transcriptional regulation observed in rainbow trout liver, where GLUT2 seems to be expressed at the same relative level irrespective of nutritional status, allowing glucose entry into hepatocytes in the postprandial state and its release during fasting (28). In mammals, decreased expression (53) of this transporter or its absence (7) occurs simultaneously with the loss of glucose-stimulated insulin secretion in numerous animal models of type 2 diabetes and, in this sense, the increase in trout GLUT2 gene expression may support a positive adaptive response of glucose transport when glycemia rises. In addition, we found that the time necessary to achieve a significant induction by glucose of GLUT2 gene expression in the piscine BB seems to be similar to that necessary in mammals (6). Accordingly, these data support the idea of an efficient adaptation to dietary carbohydrates of GLUT2 gene expression in rainbow trout BB, refusing this step of the system as responsible for the low capacity of glucose as insulin secretagogue.

The GK enzyme has been identified as a glucose sensor in pancreatic $\beta$-cells, since it has thermodynamic, kinetic, regulatory, and molecular genetic characteristics that are ideal for its function (21). Glucose is the preeminent positive regulator 

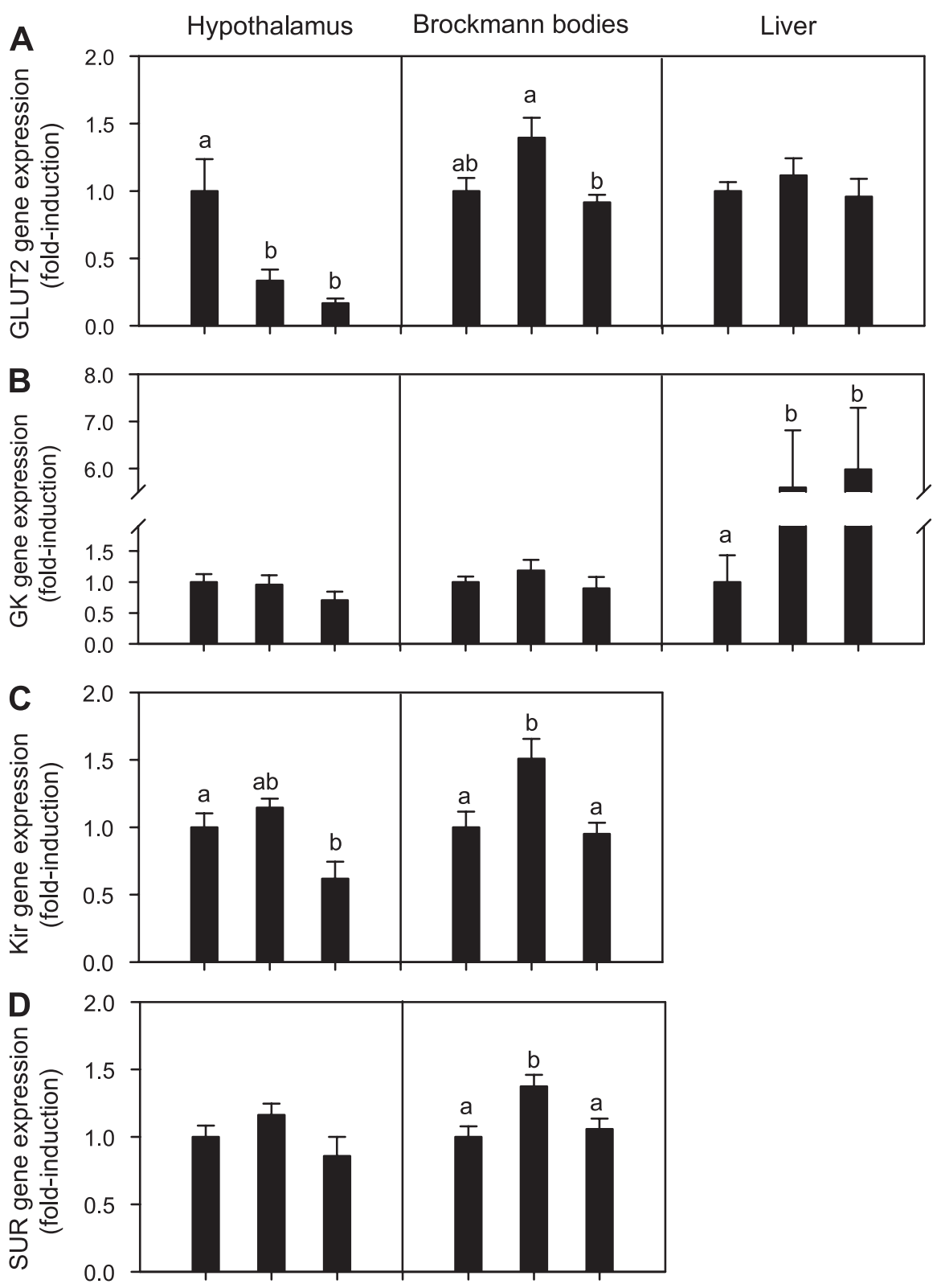

Fig. 5. GLUT2 $(A)$, GK $(B)$, Kir6.-like $(C)$, SUR-like $(D)$, and FAS $(E)$ gene expression in liver, hypothalamus and Brockmann bodies of rainbow trout fed with carbohydrates during 10 days and sampled 1,6 , and $24 \mathrm{~h}$ after the last meal. Differences in mRNA expression between times within the $\mathrm{HC}$ diet are presented as fold induction. Expression results were normalized to $\beta$-actin expression, which did not change with treatment. Values are means $\pm \mathrm{SE} ; n=$ 6. Different letters indicate significant differences $(P<0.05)$ among times within the $\mathrm{HC}$ treatment. Both SUR-like and Kir6.-like were not determinated in liver.

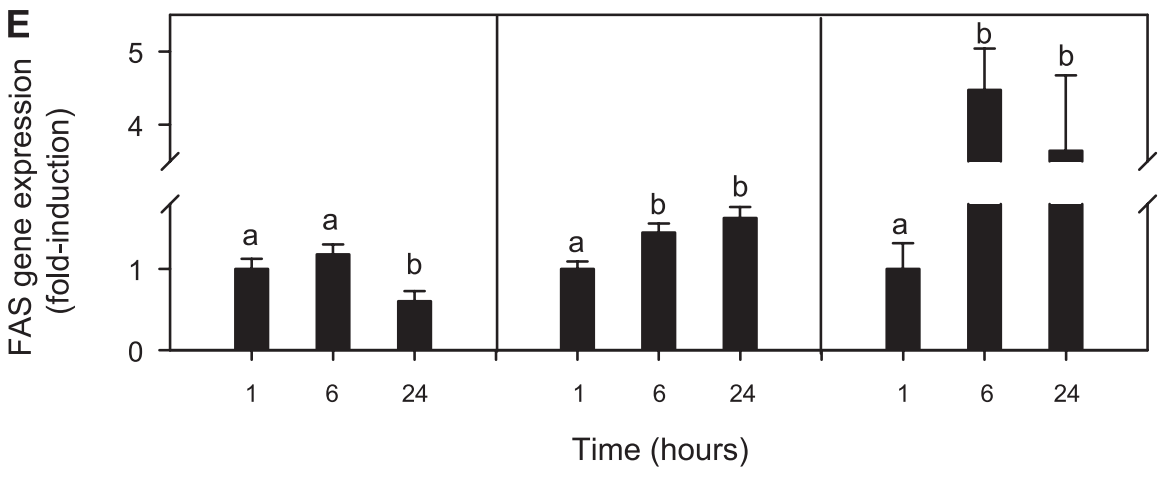

of $\beta$-cell GK expression in mammals and involves molecular mechanisms that are still to be elucidated in detail (21). In the present study, GK gene expression showed higher levels in fish fed with the $\mathrm{HC}$ diet than in those fed with the $\mathrm{CF}$ diet at least until $6 \mathrm{~h}$ postfeeding, similarly to the changes in glycemia and
GLUT2 gene expression. In previous studies in rainbow trout, we also found enhanced GK gene expression in fish fed with a $\mathrm{HC}$ diet (up to 2.2-fold at $6 \mathrm{~h}$ after feeding) in agreement with the high glucose levels observed in those animals (35) and with results in mammals (50). In previous studies in rainbow trout 

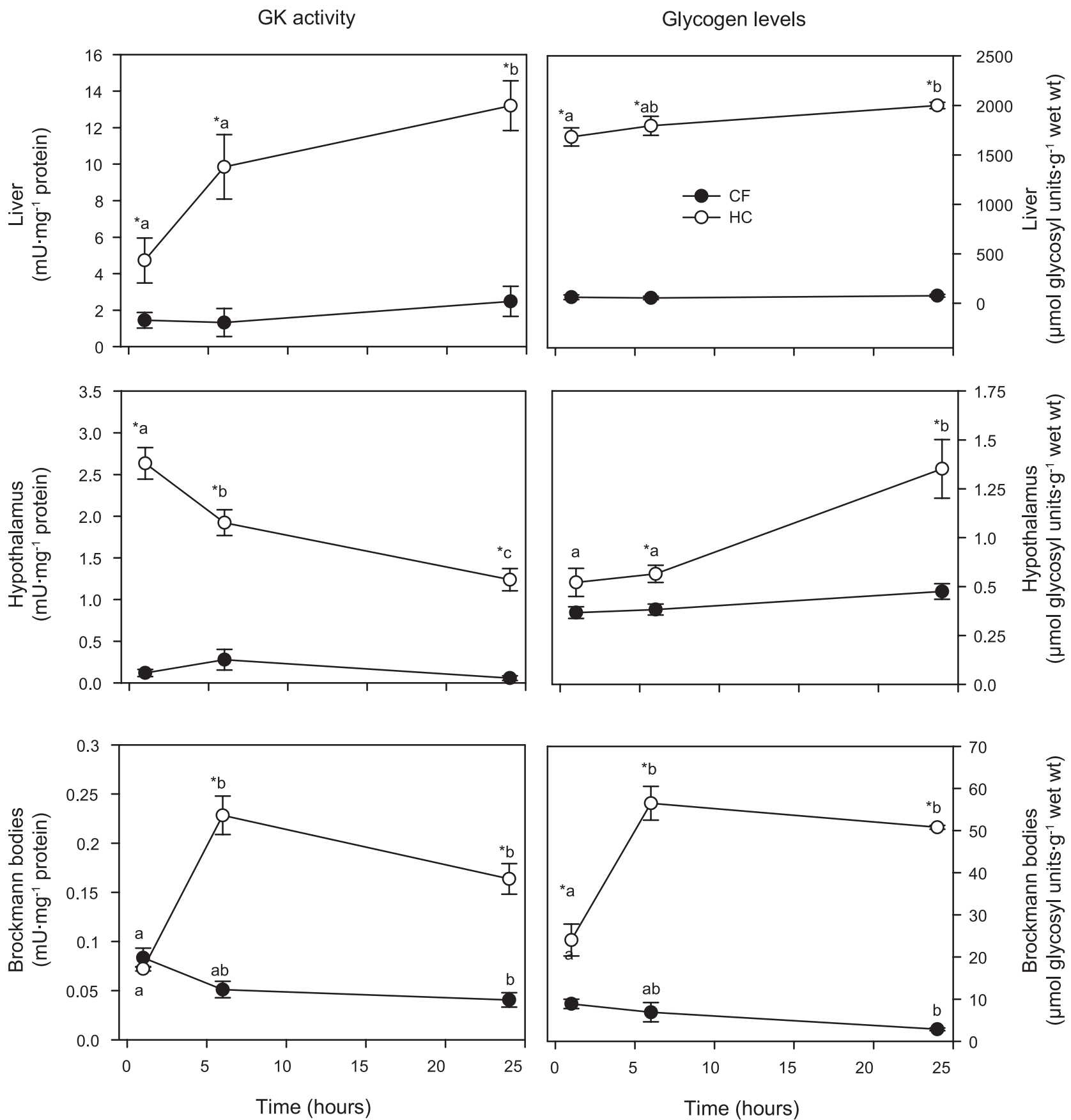

Fig. 6. GK activities and glycogen levels of rainbow trout fed with or without carbohydrates during 10 days and sampled 1,6 , and $24 \mathrm{~h}$ after the last meal. Values are means $\pm \mathrm{SE} ; n=8$. *Significantly different from CF and $\mathrm{HC}$ diets $(P<0.05)$. Different letters indicate significant differences $(P<0.05)$ among times within each treatment (CF and $\mathrm{HC})$.

fed with similar diets and where sampling points were carried out during several days (35), we found that GK activity in BB closely followed plasma glucose levels and changes in GK gene expression, reinforcing that in fish, as in mammals (50), the regulation of GK mRNA levels in pancreatic $\beta$-cells can significantly contribute to the regulation of GK enzyme activity and glucose phosphorylation. In this sense, the very low activities of GK in piscine BB (33, 52; this study) agree with the two alternative GK gene promoters in mammals (18), which keeps enzyme expression levels much lower in pancreatic $\beta$-cells than in liver parenchymal cells, making GK activ- ity in $\beta$-cells the rate-limiting step for further glucose metabolism (22). In addition, when we compared fish fed diets with or without carbohydrates $6 \mathrm{~h}$ postfeeding (maximum induction), we found that the response observed in GK activity (4.5-fold higher in fish fed with the HC diet) was stronger than that noted in GK gene expression (2.2-fold) in accordance with the predominant posttranscriptional regulation of this enzyme in mammals (5). In the adaptational process of the $\beta$-cell to hyperglycemia, the relatively high level of glycogen deposition is another characteristic change in mammalian $\beta$-cell (37), since glucose-6-phosphate produced by GK, but not hexoki- 
nase I, promotes the activation of glycogen synthase (43). In the present study, glycogen levels parallel changes in both glycemia and GK activity/expression in accordance with previous studies where fish were subjected to hyperglycemia (33, 35). Altogether, these data support the presence of the major key components of the glucosensing system in rainbow trout $\mathrm{BB}$, as was suggested previously $(33,35)$. In addition, we found an unambiguous metabolic and molecular adaptation to dietary carbohydrates in $\mathrm{BB}$ of a carnivorous fish like rainbow trout, suggesting the presence of a functional glucosensing system in this species, which may potentially generate the appropriate signal for insulin secretion.

The $\mathrm{K}_{\mathrm{ATP}}$ channel is a key component linking glucose metabolism to insulin secretion in mammalian $\beta$-cells, since the effective glucose-dependent insulin secretion requires the controlled production of $\mathrm{K}_{\mathrm{ATP}}$ channels. This is the first study, as far as we are aware, in which both Kir6.-like and SUR-like gene expression was assessed in piscine $\mathrm{BB}$, and although a formal proof will await the cloning of the full-length cDNA sequence, the high similarity between the cDNA sequences of pancreatic Kir6.-like and SUR-like in rainbow trout and the Kir6.1, Kir6.2, SUR1, SUR2A, and SUR2B sequences previously characterized in mammals (up to $75,78,73,75$, and $75 \%$ similarity, respectively) strongly suggests that these sequences correspond to the functional components of the $\mathrm{K}_{\mathrm{ATP}}$ channel in fish. In the present study, globally we found both Kir6.-like and SUR-like gene expression increased in fish fed with the $\mathrm{HC}$ diet in contrast to those fed with the CF diet. Since in mammals SUR1 mRNA levels parallel the changes in Kir6.2 mRNA levels, allowing a coordinated expression of both genes in $\beta$-cells and the formation of a functional entity by the assembly of both subunits with a stoichiometry of 1:1 (25), our data suggest that dietary carbohydrates upregulate $\mathrm{K}_{\mathrm{ATP}}$ channel gene expression in BB of rainbow trout. In contrast, in mammalian islet cells preexposed to high glucose levels, both reduced expression of $\mathrm{K}_{\mathrm{ATP}}$ channel subunits and reduced $\mathrm{K}_{\mathrm{ATP}}$ channel current amplitude occurred (25), whereas in response to glucose deprivation, channel synthesis increases rapidly by upregulating translation of existing mRNAs (44), showing a transcriptional and translational response to maintain a sustained response in insulin secretion. This striking difference with the mammalian model may provide a possible explanation for the well-known poor capacity of glucose to stimulate insulin secretion in salmonids species (23). Since in the present study dietary carbohydrates stimulated $\mathrm{K}_{\mathrm{ATP}}$ channel gene expression instead of inhibiting it, as occurs in mammals, and in rainbow trout $\mathrm{HC}$ diets were unable to reach higher insulinemia than that found in trout fed without carbohydrates $(4,26)$, we can hypothesize that this disarrangement in the glucosensing machinery may contribute to the impaired insulin secretion in trout subjected to $\mathrm{HC}$ feeding. Further studies are needed to validate this important hypothesis.

In mammals, postglycolytic events, in particular, anaplerosis and lipid signaling are thought to be implicated in $\beta$-cell activation by glucose (38). In this sense, lipid metabolism plays a role in the process whereby hyperglycemia modifies insulin secretion, and it has been reported that exposure of $\beta$-cells to elevated glucose concentration during several days induces FAS gene expression, as occurred in the present study. These results may indicate that, as occurs in mammals (38), a coordinated induction of glycolytic and lipogenic genes in conjunc- tion with glycogen deposition contributes to the adaptive process to hyperglycemia and glucose sensitization of the $\beta$-cell, supporting the efficient metabolic and molecular adaptation to dietary carbohydrates in rainbow trout BB suggested above.

Effects of dietary carbohydrates on major components of the glucosensing mechanism in the hypothalamus. Glucose detection and signaling in hypothalamic areas in mammals requires glucose uptake by GLUT2, and its presence in hypothalamic nuclei for which glucose-sensitive neurons are present has indeed been reported $(2,19)$. The minor changes observed in hypothalamic GLUT2 gene expression agree with those reported in mammals, where transport of glucose into the brain region through GLUT2 is considered not to be limiting (39). In addition, in previous studies with trout, no major changes were noticed in GLUT2 gene expression, either in glucose-injected fish (33) or in fish fed with similar diets in which the changes were concentrated in the two first days of feeding trial (35).

GK is a critical regulator of brain glucosensing in mammals (11) and fish (33), participating in the control of glucose homeostasis and food intake $(20,35)$. In the present study GK activity and expression seem to be regulated by dietary carbohydrates, since these were enhanced in fishes fed with the HC diet (at all the times assessed) in agreement with the concomitant increases in glycemia and glycogen levels in these regions. These results clearly agree with the model described in fish in previous studies with rainbow trout, where enhanced glucose levels due to intraperitoneal/intracerebroventricular glucose administration $(33,36)$ or long-term feeding of $\mathrm{HC}$ diets (35) promoted changes in these glucosensing-related parameters. Altogether, these results suggest that dietary carbohydrates increase plasma glucose levels, which are detected in this glucosensing area through a typical metabolic response characterized by higher GK activities and glycogen levels, and that they are probably involved in the initiation of the neural response to the hyperglycemia (35).

In mammals, the involvement of $\mathrm{K}_{\mathrm{ATP}}$ channel in central glucose recognition and counterregulation has been demonstrated in numerous studies (20). However, in fish, this is the first time in which the $\mathrm{K}_{\mathrm{ATP}}$ channel is studied in the hypothalamus, providing evidence for the expression of both Kir6.like and SUR-like in a way similar to several hypothalamic nuclei in mammals (20). Although dietary carbohydrates do not seem to regulate $\mathrm{K}_{\text {ATP }}$ gene expression in trout hypothalamus in opposition to the downregulation observed in hyperglycemic rats (1), the presence of the $\mathrm{K}_{\mathrm{ATP}}$ channel in the mammalian hypothalamus is at the core of the capacity of glucosensing neurons to alter their membrane potential in response to changes in glucose (40), suggesting a similar role in fish. In addition, functional $\mathrm{K}_{\mathrm{ATP}}$ channels have been identified in the hypothalamic areas important for the control of food intake and energy balance (1) in agreement with the results in the present study and with the changes in the glucosensing potential in rainbow trout subjected to hypoand hyperglycemia where changes in food intake were also noticed (35).

In accordance with the critical functions of hypothalamic neurons in the regulation of glucose homeostasis, energy expenditure, and food intake (20), we also studied FAS gene expression, which has been hypothesized in mammals to contribute to the regulation of energy balance and metabolic homeostasis in this brain region (14). Indeed, we found FAS 
gene expression in trout hypothalamus, which may suggest that this enzyme plays a significant role in energy homeostasis in fish as in mammals. However, FAS gene expression was not affected by dietary carbohydrates in trout hypothalamus in opposition to the upregulation reported in both rat hypothalamic neurons subjected to high glucose concentrations (14) and hepatic FAS expression (this study). This tissue-dependent response noted in FAS gene expression demonstrates how nutrients (like glucose) can regulate differentially in fish key metabolic genes in both peripheral and central tissues, reflecting different functions for different tissues in response to the same nutritional signal.

Postprandial effects of dietary carbohydrates on major components of the glucosensing mechanism. In fish fed with the carbohydrate-enriched diet, we also assessed the postprandial profile of gene expression of the major components of the glucosensing mechanism, as well as the associated major biochemical parameters (GK activity and glycogen levels). This is the first study, as far as we are aware, in which such postprandial kinetic characterization was carried out. In accordance with the typical glycemia profile found in salmonids fed with a $\mathrm{HC}$ diet (see above) and the slow digestive process in fish (8) we found a differential response in the profile of both biochemical parameters and gene expression of major glucosensing components due to dietary carbohydrates in the three tissues studied. In the hypothalamus, we observed the highest GLUT2 gene expression $1 \mathrm{~h}$ after feeding, in agreement with the maximal GK activity at that time, and a decrease thereafter between 6 and $24 \mathrm{~h}$ postfeeding. Since fish were regularly fed once a day, data obtained $24 \mathrm{~h}$ after feeding very likely also represent the prefeeding situation $(0 \mathrm{~h})$ with fish waiting for the next meal, and because of that, both parameters probably increased after the meal. In contrast, this increase in gene expression was delayed until $6 \mathrm{~h}$ postfeeding in $\mathrm{BB}$, where in general, we observed the maximum values at that time. Again, the increase in GK activity was also found $6 \mathrm{~h}$ after feeding, even considering that no significant differences were achieved in gene expression. Finally, as occurred in BB and in opposition to the hypothalamus, we found the maximum GK activity and expression in liver between 6 and $24 \mathrm{~h}$ postfeeding, similar to previous results described in teleost fishes (27). Altogether, these data demonstrate in fish the existence of different postprandial profiles in both key glucosensing genes and biochemical parameters in response to dietary carbohydrates in different trout tissues. Thereby, since the hypothalamus seems to respond to hyperglycemia earlier than BB or liver, we suggest that in trout nutrients like glucose are able to regulate differentially the glucosensing system in peripheral and central tissues. In addition, we found that the liver, which is not acting as a glucosensor tissue, is the last tissue responding to hyperglycemia, supporting the idea that the physiologically relevant glucosensor mechanism is a short-term system placed in brain regions and pancreatic cells and not the liver, which is associated with other functions.

In the present study, we describe for the first time in fish the presence of two new key components of the glucosensing mechanism proposed in mammals (Kir and SUR; Ref. 42) in two glucosensor tissues (hypothalamus and BB; Ref. 33) of rainbow trout, as well as confirmed the presence of other two (GLUT2 and GK) by qPCR. In addition, after rainbow trout were fed with two experimental diets (CF and $\mathrm{HC}$ ) for 10 days, we demonstrated in this species a potential capacity to respond to a $\mathrm{HC}$ diet at a molecular level, based on a positive response of the major components of the glucosensing system. We found that these four genes were strongly upregulated by dietary carbohydrates in BB, especially $6 \mathrm{~h}$ after feeding, suggesting a maximum capacity to respond to glucose at that time and an efficient adaptation to this amount of carbohydrates. In contrast, in the hypothalamus only GK gene expression was upregulated by dietary carbohydrates, reinforcing the key role of this enzyme in the central glucodetection, as occurs in mammals (11). On the other hand, we also found a differential postprandial regulation of the system by dietary carbohydrates. Those profiles were characterized by an earlier response in some of the components of the system in the hypothalamus and a delayed regulation in $\mathrm{BB}$, suggesting that the brain is the first organ detecting and responding to an increase in glycemia, in agreement with the glucose dependence of this tissue in mammals (20) and fish (46), while the pancreas potential response would be produced later.

\section{Perspectives and Significance}

Altogether, these results demonstrate an efficient adaptation and the potential capacity to respond to a $\mathrm{HC}$ diet in rainbow trout that do not support the originally hypothesis $(24,55)$ that the limited capacity to utilize dietary carbohydrates in this species was due to the lack of a glucosensing system. In this sense, although this glucosensing system seems to be functional at the molecular level in rainbow trout hypothalamus and $\mathrm{BB}$, in a practice point of view, this species still an inefficient user of dietary carbohydrates. This glucose intolerance could be related to the behavior of some components of the system in rainbow trout BB (Kir and SUR) that changed in an opposite way compared with the mammalian system and suggest a disarrangement in the metabolic pathway that leads to insulin secretion, linked to glucose intolerance in trout. However, the efficient adaptation to dietary carbohydrates found in the glucosensing tissues of rainbow trout could indicate that the glucose intolerance in this species is not related with glucose detection. Therefore, the basis of this poor ability to efficiently utilize dietary carbohydrates in rainbow trout remains to be elucidated and could be related to other molecular events, such as signaling pathways or interaction with other nutrients present in the diet, like amino acids.

\section{GRANTS}

This study was supported by research grants from the Ministerio de Educación y Ciencia and European Fund for Regional Development (AGL2004-08137-c0403/ACU), the Xunta de Galicia (PGIDT05PXIC31202PN), and the $6^{\text {th }}$ PCRD European Project (contract no. 016249-2) "Sustainable Aquafeeds to Maximise the Health Benefits of Farmed Fish for Consumers (AQUAMAX).” S. Polakof was recipient of a predoctoral fellowship from the Xunta de Galicia (Program Maria Barbeito).

\section{REFERENCES}

1. Acosta-Martínez M, Levine JE. Regulation of $\mathrm{K}_{\mathrm{ATP}}$ channel subunit gene expression by hyperglycemia in the mediobasal hypothalamus of female rats. Am J Physiol Endocrinol Metab 292: E1801-E1807, 2007.

2. Arluison M, Quignon M, Nguyen P, Thorens B, Leloup C, Penicaud L. Distribution and anatomical localization of the glucose transporter 2 (GLUT2) in the adult rat brain-an immunohistochemical study. $J$ Chem Neuroanat 28: 117-136, 2004.

3. Borrebaek B, Christophersen B. Activities of glucose phosphorylation, glucose-6-phosphatase and lipogenic enzymes in the liver of perch, Perca 
fluviatilis, after different dietary treatment. Aquac Res 32, Suppl 1: 221-224, 2001.

4. Capilla E, Médale F, Navarro I, Panserat S, Vachot C, Kaushik S, Gutiérrez J. Muscle insulin binding and plasma levels in relation to liver glucokinase activity, glucose metabolism and dietary carbohydrates in rainbow trout. Regul Pept 110: 123-132, 2003.

5. Chen C, Hosokawa H, Bumbalo LM, Leahy JL. Regulatory effects of glucose on the catalytic activity and cellular content of glucokinase in the pancreatic beta cell. Study using cultured rat islets. J Clin Invest 94: 1616-1620, 1994.

6. Ferrer J, Gomis R, Fernandez AJ, Casamitjana R, Vilardell E. Signals derived from glucose metabolism are required for glucose regulation of pancreatic islet GLUT2 mRNA and protein. Diabetes 42: 1273-1280, 1993.

7. Guillam MT, Dupraz P, Thorens B. Glucose uptake, utilization, and signaling in GLUT2-null islets. Diabetes 49: 1485-1491, 2000

8. Guillaume J, Choubert G. Digestive physiology and nutrient digestibility in fishes. In: Nutrition and Feeding of Fish and Crustaceans, edited by Guillaume J, Kaushik S, Bergot P, Métailler R. Chichester, UK: Springer, 2001, p. 27-56.

9. Heimberg H, De Vos A, Pipeleers D, Thorens B, Schuit F. Differences in glucose transporter gene expression between rat pancreatic alpha- and beta-cells are correlated to differences in glucose transport but not in glucose utilization. J Biol Chem 270: 8971-8975, 1995.

10. Hemre GI, Sandnes K, Lie $\emptyset$, Waagbø R. Blood chemistry and organ nutrient composition in Atlantic salmon, Salmo salar L., fed graded amounts of wheat starch. Aquac Nutr 1: 37-42, 1995.

11. Kang L, Dunn-Meynell AA, Routh VH, Gaspers L, Nagata Y, Nishimura T, Eikis J, Zhang BB, Levin BE. Glucokinase is a critical regulator of ventromedial hypothalamic neuronal glucosensing. Diabetes 55: 412-420, 2006.

12. Kaushik S, Médale F. Energy requirements, utilization and dietary supply to salmonids. Aquaculture 124: 81-97, 1994.

13. Keppler D, Decker K. Glycogen determination with amyloglucosidase. In: Methods of Enzymatic Analysis, edited by Bergmeyer HU. New York: Academic Press, 1974, p. 1127-1131.

14. Kim EK, Kleman AM, Ronnett GV. Fatty acid synthase gene regulation in primary hypothalamic neurons. Neurosci Lett 423: 200-204, 2007.

15. Kirchner S, Seixas P, Kaushik S, Panserat S. Effects of low protein intake on extra-hepatic gluconeogenic enzyme expression and peripheral glucose phosphorylation in rainbow trout (Oncorhynchus mykiss). Comp Biochem Physiol 140B: 333-340, 2005.

16. Levin BE, Routh VH, Kang L, Sanders NM, Dunn-Meynell AA. Neuronal glucosensing What do we know after 50 years? Diabetes 53: 2521-2528, 2004.

17. MacCormack TJ, Driedzic WR. The impact of hypoxia on in vivo glucose uptake in a hypoglycemic fish, Myoxocephalus scorpius. Am J Physiol Regul Integr Comp Physiol 292: R1033-R1042, 2007.

18. Magnuson MA, Shelton KD. An alternate promoter in the glucokinase gene is active in the pancreatic beta cell. J Biol Chem 264: 15936-15942, 1989.

19. Marty N, Dallaporta M, Foretz M, Emery M, Tarussio D, Bady I, Binnert C, Beermann F, Thorens B. Regulation of glucagon secretion by glucose transporter type 2 (GLUT2) and astrocyte-dependent glucose sensors. J Clin Invest 115: 3545-3553, 2005.

20. Marty N, Dallaporta M, Thorens B. Brain glucose sensing, counteregulation, and energy homeostasis. Physiology 22: 241-251, 2007.

21. Matschinsky FM. Regulation of pancreatic beta-cell glucokinase: from basics to therapeutics. Diabetes 51, Suppl 3: S394-S404, 2002.

22. Matschinsky FM, Glaser B, Magnuson MA. Pancreatic $\beta$-cell glucokinase. Closing the gap between theoretical concepts and experimental realities. Diabetes 47: 307-315, 1998.

23. Mommsen TP, Moon TW, Plisetskaya EM. Effecs of arginine on pancreatic hormones and hepatic metabolism in rainbow trout. Physiol Biochem Zool 74: 668-678, 2001.

24. Moon TW. Glucose intolerance in teleost fish: fact or fiction? Comp Biochem Physiol 129B: 243-249, 2001.

25. Moritz W, Leech CA, Ferrer J, Habener JF. Regulated expression of adenosine triphosphate-sensitive potassium channel subunits in pancreatic beta-cells. Endocrinology 142: 129-138, 2001.

26. Novoa MS, Capilla E, Rojas P, Baro J, Gutiérrez J, Navarro I. Glucagon and insulin response to dietary carbohydrate in rainbow trout (Oncorhynchus mykiss). Gen Comp Endocrinol 139: 48-54, 2004.

27. Panserat S, Médale F, Blin C, Brèque J, Vachot C, Plagnes-Juan E, Gomes E, Krishnamoorthy R, Kaushik S. Hepatic glucokinase is induced by dietary carbohydrates in rainbow trout, gilhead seabream, and common carp. Am J Physiol Regul Integr Comp Physiol 278: R1164-R1170, 2000.

28. Panserat S, Plagnes-Juan E, Kaushik S. Nutritional regulation and tissue specificity of gene expression for proteins involved in hepatic glucose metabolism in rainbow trout (Oncorhynchus mykiss). J Exp Biol 204: 2351-2360, 2001.

29. Paulauskis JD, Sul HS. Hormonal regulation of mouse fatty acid synthase gene transcription in liver. J Biol Chem 264: 574-577, 1989.

30. Pfaffl MW. A new mathematical model for relative quantification in real-time RT-PCR. Nucleic Acids Res 29: e45, 2001.

31. Plagnes-Juan E, Lansard M, Seiliez I, Médale F, Corraze G, Kaushik S, Panserat S, Skiba-Cassy S. Insulin regulates the expression of several metabolism-related genes in the liver and primary hepatocytes of rainbow trout (Oncorhynchus mykiss). J Exp Biol 211: 2510-2518, 2008.

32. Polakof S, Ceinos RM, Fernández-Durán B, Míguez JM, Soengas JL. Daily changes in parameters of energy metabolism in brain of rainbow trout: dependence on feeding. Comp Biochem Physiol 146A: 265-273, 2007.

33. Polakof S, Míguez JM, Moon TW, Soengas JL. Evidence for the presence of a glucosensor in hypothalamus, hindbrain, and Brockmann bodies of rainbow trout. Am J Physiol Regul Integr Comp Physiol 292: R1657-R1666, 2007.

34. Polakof S, Míguez JM, Soengas JL. In vitro evidences for glucosensing capacity and mechanisms in hypothalamus, hindbrain, and Brockmann bodies of rainbow trout. Am J Physiol Regul Integr Comp Physiol 293: R1410-R1420, 2007.

35. Polakof S, Míguez JM, Soengas JL. Dietary carbohydrates induce changes in glucosensing capacity and food intake of rainbow trout. Am J Physiol Regul Integr Comp Physiol 295: R478-R489, 2008.

36. Polakof S, Soengas JL. Involvement of lactate in glucose metabolism and glucosensing function in selected tissues of rainbow trout. J Exp Biol 211: 1075-1086, 2008.

37. Roche E, Assimacopoulos-Jeannet F, Witters LA, Perruchoud B, Yaney G, Corkey B, Asfari M, Prentki M. Induction by glucose of genes coding for glycolytic enzymes in a pancreatic $\beta$-cell line (INS-1). J Biol Chem 272: 3091-3098, 1997.

38. Roche E, Farfari S, Witters LA, ssimacopoulos-Jeannet F, Thumelin S, Brun T, Corkey BE, Saha AK, Prentki M. Long-term exposure of beta-INS cells to high glucose concentrations increases anaplerosis, lipogenesis, and lipogenic gene expression. Diabetes 47: 1086-1094, 1998.

39. Roncero I, Álvarez E, Chowen JA, Sanz C, Rábano A, Vázquez P, Blázquez E. Expression of glucose transporter isoform GLUT-2 and glucokinase genes in human brain. J Neurochem 88: 1203-1210, 2004.

40. Rother E, Konner AC, Bruning JC. Neurocircuits integrating hormone and nutrient signaling in control of glucose metabolism. Am J Physiol Endocrinol Metab 294: E810-E816, 2008.

41. Sánchez-Muros MJ, García-Rejón L, García-Salguero L, De la Higuera M, Lupiáñez JA. Long-term nutritional effects on the pimary liver and kidney metabolism in rainbow trout. Adaptative response to starvation and high-protein, carbohydrate-free diet to glutamate dehydrogenase and alanine aminotransferase kinetics. Int J Biochem 30: 55-63, 1998.

42. Schuit FC, Huypens P, Heimberg H, Pipeleers DG. Glucose sensing in pancreatic $\beta$-cells. A model for the study of other glucose-regulated cells in gut, pancreas, and hypothalamus. Diabetes 50: 1-11, 2001

43. Seoane J, Gómez-Foix AM, O’Doherty RM, Gómez-Ara C, Newgard CB, Guinovart JJ. Glucose 6-phosphate produced by glucokinase, but not hexokinase I, promotes the activation of hepatic glycogen synthase. J Biol Chem 271: 23756-23760, 1996.

44. Smith AJ, Partridge CJ, Asipu A, Mair LA, Hunter M, Sivaprasadarao A. Increased ATP-sensitive $\mathrm{K}^{+}$channel expression during acute glucose deprivation. Biochem Biophys Res Commun 348: 1123-1131, 2006.

45. Smith PK, Krohn RI, Hermanson GT, Mallia AK, Gartner FH, Provenzano MD, Fujimoto EK, Goeke NM, Olson BJ, Klenk DC. Measurement of protein using bicinchoninic acid. Anal Biochem 150: 76-85, 1985.

46. Soengas JL, Aldegunde M. Energy metabolism of fish brain. Comp Biochem Physiol 131B: 271-296, 2002.

47. Tapia-Salazar M, Bureau W, Panserat S, Corraze G, Bureau DP. Effect of DHA supplementation on digestible starch utilization by rainbow trout. Br J Nutr 95: 76-87, 2006.

48. Thivend P, Christiane M, Guilbot A. Determination of starch with glucoamylase. Methods Carbohydr Chem 6: 100-105, 1972.

49. Thorens B, Sarkar HK, Kaback HR, Lodish HF. Cloning and functional expression in bacteria of a novel glucose transporter present in liver, intestine, kidney, and beta-pancreatic islet cells. Cell 55: 281-290, 1988. 
50. Tiedge M, Lenzen S. Effects of glucose refeeding and glibenclamide treatment on glucokinase and GLUT2 gene expression in pancreatic $\beta$-cells and liver from rats. Biochem J 308: 139-144, 1995.

51. Towle HC, Kaytor EN, Shih HM. Regulation of the expression of lipogenic enzyme genes by carbohydrate. Аппи Rev Nutr 17: 405-433, 1997.

52. Tranulis MA, Dregni O, Christophersen B, Krogdahl Å, Borrebaek B. A glucokinase-like-enzyme in the liver of Atlantic salmon (Salmo salar). Comp Biochem Physiol 114A: 35-39, 1996.

53. Unger RH. Diabetic hyperglycemia: link to impaired glucose transport in pancreatic beta cells. Science 251: 1200-1205, 1991.
54. Waeber G, Thompson N, Haefliger JA, Nicod P. Characterization of the murine high $\mathrm{K}_{\mathrm{m}}$ glucose transporter GLUT2 gene and its transcriptional regulation by glucose in a differentiated insulin-secreting cell line. J Biol Chem 269: 26912-26919, 1994.

55. Wilson RP. Utilization of dietary carbohydrate by fish. Aquaculture 124: 67-80, 1994.

56. Youson JH, Al-Mahrouki AA, Anemiya Y, Graham LC, Montpetit CJ, Irwin DM. The fish endocrine pancreas: research update and future directions in ontogenic and phylogenetic development. Gen Comp Endocrinol 148: 105-115, 2006.

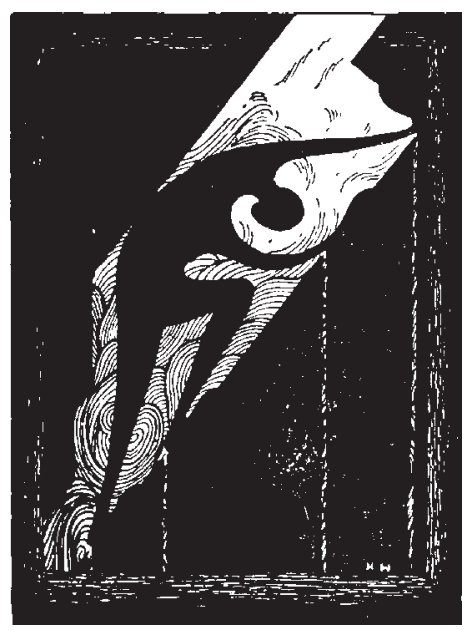

